\title{
KETERAMPILAN GURU PENDIDIKAN AGAMA KRISTEN UNTUK MENINGKATKAN MINAT BELAJAR MURID DI KELAS
}

\author{
Darwis L. Laana*1, Dorce Sondopen ${ }^{2}$ \\ ${ }^{1,2}$ Sekolah Tinggi Teologi Excelsius \\ *darwislaana23@gmail.com
}

\begin{abstract}
One of the challenges in the teaching and learning process in the classroom is that students are less enthusiastic. The teacher's expectation during teaching in class is that all students can be enthusiastic and full of interest in learning. But in reality it is not like that, because not all teachers have the ability to solve the problems of students who are less enthusiastic. Therefore, the study of teacher skills in increasing student interest in learning is needed. The purpose of this study is to encourage teachers to add skills in carrying out their duties so that students learn more seriously. The author uses a qualitative descriptive method, namely explaining the terms used in the title of the article based on related sources. The important point of the results in this study is that teachers must have the skills to manage the classroom well. The teacher must master the skills from opening to closing class. The teacher must have skills in asking, explaining, giving reinforcement, and also in making deep variations. These classroom management skills have a big influence on students' attention to learning.
\end{abstract}

\section{Keywords: Skills, Teachers, Students, Interest in Learning}

\begin{abstract}
Abstrak: Salah satu tantangan dalam proses belajar mengajar di kelas ialah murid kurang antusias. Harapan guru selama mengajar di kelas adalah semua murid dapat antusias dan penuh minat belajar yang tinggi. Namun dalam kenyataannya tidak seperti itu, sebab tidak semua guru memiliki kemampuan dalam mengatasi masalah murid yang kurang antusias. Maka itu kajian tentang keterampilan guru dalam meningkatkan minat murid untuk belajar sangat dibutuhkan. Tujuan dari kajian ini untuk mendorong guru menambah keterampilan dalam melaksanakan tugasnya sehingga murid belajar dengan lebih serius. Penulis menggunakan metode deskriptif kualitatif yaitu menjelaskan istilah-istilah yang digunakan pada judul tulisan berdasarkan sumber yang berkaitan. Poin penting hasil dalam kajian ini adalah guru harus memiliki ketrampilan untuk mengelola kelas dengan baik. Guru harus menguasai keterampilan untuk memulai pembukaan sampai pada menutup kelas. Guru harus memiliki keterampilan dalam bertanya, menjelaskan, memberi penguatan, dan juga dalam membuat variasi dalam. Keterampilan dalam pengelolaan kelas ini berpengaruh besar terhadap perhatian murid untuk belajar.
\end{abstract}

Kata Kunci: Keterampilan, Guru, Murid, Minat Belajar 


\section{PENDAHULUAN}

Dalam proses belajar mengajar yang berlangsung di kelas akan berjalan dengan baik jika terjadi interaksi yang optimal antara murid dan guru dalam rangka mencapai suatu tujuan yang telah disepakati. Salah satu tujuan pembelajaran yang ingin dicapai adalah murid dapat memperoleh prestasi belajar yang optimal. Seorang guru bukan hanya sekedar mengajar dan memberikan ilmu pengetahuan begitu saja tetapi memiliki peran yang sangat strategis bagaimana caranya membuat suasana belajar yang menarik dan menyenangkan sehingga murid dengan antusias mengikuti pelajaran dan dengan mudah memahami materi pelajaran yang diterimanya.

Pada kenyataannya, guru tidak selalu mampu mewujudkan tercapainya tujuan tersebut karena rendahnya minat siswa untuk belajar. Guru tidak mampu menjadi adalah seorang komunikator yang baik karena posisinya adalah: (1) faktor dosa dan (2) faktor psikologis (social perception, frame of reference, mood, dan attitude). ${ }^{1}$ Dampaknya tentu kurang baik yaitu murid tidak dapat menguasai kompetensi atau tujuan pelajaran tersebut. Pembelajaran di kelas tidak jarang masih dalam suasana belajar yang monoton, sehingga murid tidak bisa mengembangkan kreativitasnya, dan murid tidak tampak antusias dalam mengikuti pelajaran di kelas. Pada proses pembelajaran masa kini tidak bisa menghindar dari apa yang sudah dilakukan secara konvensional dimana guru memberikan ceramah secara teoritis, memberikan tugas kemudian memberikan tes akhir dimana hal ini akan terulang secara terus menerus. Cara pembelajaran seperti ini memang memiliki kecenderungan yang besar bagi murid untuk menjadi bosan dan akhirnya tujuan pembelajaran bisa tidak tercapai.

Maka dari itu tugas guru sangat besar yaitu untuk membalikkan keadaan yang membosankan menjadi suasana yang menyenangkan sehingga murid memiliki minat belajar yang tinggi. Tuntutan guru bukan hanya sekedar transfer ilmu kepada murid tetapi juga menciptakan suasana kelas

${ }^{1}$ Harianto GP, Komunikasi dalam Pemberitaan Injil (Yogjakarta: Andi,2012), 13. 28 | Vol. 2 No. 2 (Juli-Desember 2018) yang menyenangkan. Maka itu guru harus memiliki ketrampilan yang diperlukan untuk memastikan proses belajar di kelas bukan saja berjalan lancar tetapi juga menyenangkan. Guru Pendidikan Agama Kristen tentu mempunyai keunikan dibandingkan dengan guru-guru umum lainnya. Perbedaannya terletak pada karakter hidup seorang guru Kristen, karena seorang yang lahir dan hidup di dalam kekristenan pasti sudah mengetahui dan mengenal sosok pribadi yang penuh kasih, dan berkarakter sempurna yaitu Yesus Kristus. Sehingga seorang guru Kristen dituntut untuk hidup sesuai dengan karakter Kristus, demikian juga dalam cara mengajarnya tentu akan mengacu pada bagaimana Tuhan Yesus mengajar.

\section{PEMBAHASAN}

\section{Ketrampilan Guru Pendidikan Agama Kristen}

Dalam Kamus Besar Bahasa Indonesia keterampilan ialah kecakapan untuk menyelesaikan tugas. Maka dalam tulisan ini keterampilan dapat diartikan sebagai kemampuan untuk menggunakan akal, fikiran, ide dan kreatifitas dalam mengerjakan, mengubah ataupun membuat sesuatu sehingga lebih bermakna untuk menghasilkan sebuah nilai dari hasil pekerjaan tersebut. ${ }^{2}$

Menurut Undang-Undang no 14 tahun 2005 guru adalah pendidik profesional dengan tugas utama mendidik, mengajar, membimbing, mengarahkan, melatih, menilai, dan mengevaluasi peserta didik pada pendidikan anak usia dini jalur pendidikan formal, pendidikan dasar, dan pendidikan menengah. ${ }^{3}$

Usman mengatakan guru merupakan jabatan atau profesi yang memerlukan keahlian khusus, sehingga, sebagai guru yang profesioanal yaitu orang yang memiliki kemampuan dan keahlian khusus dalam bidang keguruan sehingga ia mampu melakukan tugas dan fungsinya sebagai guru

\footnotetext{
${ }^{2}$ Tim Penyusun, Kamus Besar Bahasa Indonesia (Jakarta: Balai Pustaka, 2001), 1088.

${ }^{3}$ Undang Undang Republik Indonesia No 14 Tahun 20005 tentang Guru dan Dosen (Jakarta: Depdiknas, 2005).
} 
dengan kemampuan khusus. ${ }^{4}$

Suparlan mengatakan bahwa guru dapat diartikan sebagai orang yang tugasnya terkait dengan upaya mencerdaskan kehidupan bangsa dalam semua aspeknya, baik spiritual dan emosional, intelektual, fisikal, maupun aspek lainnya. Secara legal formal, guru adalah seseorang yang memperoleh surat keputusan (SK), baik dari pemerintah maupun pihak swasta untuk mengajar. $^{5}$

Dari pengertian tersebut dapat artikan bahwa guru adalah seorang yang memiliki keahlian dan kemampuan khusus dalam bidangnya. Dengan demikian dapat dikatakan bahwa hakikat keterampilan guru adalah kecakapan dari seorang tenaga profesional yang tugas utamanya ialah mendidik, mengajar, membimbing, mengarahkan, melatih, menilai, dan mengevaluasi dalam mengubah atau membuat sesuatu yang dikerjakan menjadi lebih bermakna.

\section{Pengertian Pendidikan Agama Kristen}

Menurut Undang-Undang Republik Indonesia Nomor 20 Tahun 2003 tentang Sistem Pendidikan Nasional atau yang lebih dikenal dengan sebutan Undang-Undang Sistem Pendidikan Nasional (UUSPN) Bab I pasal 1 dinyatakan bahwa pendidikan adalah usaha sadar dan terencana untuk mewujudkan suasana belajar dan proses pembelajaran agar peserta didik secara aktif mengembangkan potensi dirinya untuk memiliki kekuatan spiritual keagamaan, pengendalian diri, kepribadian, kecerdasan, akhlak mulia, serta keterampilan yang diperlukan dirinya, masyarakat, bangsa, dan negara. Secara etimologis pendidikan berasal dari kata latin 'educates' dengan istilah educare atau educere yang berarti merawat dan melengkapi dan juga membimbing keluar.

Sijabat mengatakan bahwa pendidikan adalah sebagai upaya sadar dan sengaja untuk memperlengkapi seseorang atau kelompok orang untuk membimbingnya keluar dari suatu tahapan (keadaan) hidup ke suatu

\footnotetext{
${ }^{4}$ Uzer Usman, Menjadi Guru Profesional (Jakarta: Remaja Rosdakarya, 2006), 5.

${ }^{5}$ Suparlan, Menjadi Guru Efektif (Jakarta: Hikayat Publishing, 2008), 12-13.
}

tahapan hidup lainnya yang lebih baik. ${ }^{6}$

Menurut Kamus Besar Bahasa Indonesia, agama adalah sistem yang mengatur tata keimanan (kepercayaan) dan peribadatan kepada Tuhan Yang Maha Kuasa serta tata kaidah yang berhubungan pergaulan manusia dengan sesama dan lingkungannya. Agama Kristen adalah suatu sistem kepercayaan atau ajaran yang yang bersumber dan bermuara kepada Allah didalam Yesus Kristus. Sistem kepercayaan atau ajaran yang meyakini bahwa tindakan Allah yang dalam kasihNya mencari dan menyelamatkan manusia (Rm. 5:8, Yoh. 3: Ef. 2:8-9). Maka, dapat dikatakan Pendidikan Agama Kristen adalah proses pengajaran dan pembelajaran yang berdasarkan Alkitab, berpusat pada Kristus dan bergantung kepada Roh Kudus yang membimbing setiap pribadi pada semua tingkat pertumbuhan melalui pengajaran masa kini ke arah pengenalan dan pengalaman rencana dan kehendak Allah melalui Kristus dalam setiap aspek kehidupan, dan melengkapi bagi pelayanan yang efektif, yang berpusat pada Kristus sang Guru Agung.

Nainggolan tujuan dari Pendidikan Agama Kristen adalah mengajarkan Firman Tuhan, membawa perjumpamaan dengan Kristus, mengajarkan hidup bersama, dan membawa murid untuk memiliki spiritualitas seperti Kristus. Materi utama dalam Pendidikan Agama Kristen adalah Alkitab karena Alkitab adalah Firman Allah yang tertulis. Sehingga pusat akhir dari belajar Pendidikan Agama Kristen adalah memiliki karakter seperti karakter Tuhan Yesus Kristus. 7 Lebih dalam, Harianto GP mengatakan bahwa Pendidikn Agama Kristen memberi sumbangsih kognitif, afektif dan skill tentang pemahaman dan praktik PAK dalam kehidupan seseorang yang menyangkut seluruh kepribadiannya. ${ }^{8}$

\section{Minat Belajar Murid dalam Proses Pembelajaran di Kelas}

\footnotetext{
${ }^{6}$ Samuel Sijabat, Strategi Pendidikan Kristen (Yogjakarta: Andi, 1994),15.

${ }^{7}$ Johan M. Nainggolan, Menjadi Guru Agama Kristen (Jakarta: Generasi Info Media, 2007), 120.

${ }^{8}$ Harianto GP, Pendidikan Agama Kristen dalam Alkitab \& Dunia Pendidikan Masa Kini (Yogjakarta: Andi, 2012), 60.
}

Excelsis Deo: Jurnal Teologi, Misiologi, dan Pendidikan | 29 
Menurut Kamus Besar Bahasa Indonesia Minat adalah sebagai perhatian, kecenderungan hati terhadap sesuatu, gairah, atau keinginan. Nurhayati mengatakan minat adalah kecenderugan terhadap sesuatu, atau bisa dikatakan apa yang disukai seseorang terhadap sesuatu atau apa yang disukai seseorang untuk dilakukan. ${ }^{9}$

Susanto mengatakan timbulnya minat pada seseorang dapat digolongkan menjadi dua jenis yaitu minat murid yang berasal dari bawaan dan minat murid yang timbul karena pengaruh dari luar dirinya. Minat bawaan timbul dengan sendirinya dari setiap individu. Sedangkan minat yang timbul karena adanya pengaruh dari luar dirinya timbul seiring dengan perkembangan individu yang bersangkutan. Dan minat ini sangat dipengaruhi oleh lingkungannya, adat atau kebiasaan, orang tua, guru, dan juga temantemannya. ${ }^{10}$

Minat merupakan kekuatan motivasi, sehingga ada beberapa hal yang perlu diperhatikan dalam mencerminkan ada tidaknya minat dalam diri murid sebagai berikut: Pertama, perasaan senang, jika seorang murid memiliki perasaan senang terhadap mata pelajaran Pendidikan Agama Krsten karena dari perasaan senang ini akan mengusir rasa bosan dalam belajar. Kedua, perhatian yang merupakan konsentrasi atau aktivitas jiwa seorang murid terhadap apa yang sedang dijalani dengan mengesampingkan hal lainnya. Ketiga, memiliki pengetahuan dan rasa ingin tahu lebih karena rasa ingin tahu lebih terhadap apa yang sudah diketahuinya itu mencerminkan tingkat minat dari seorang murid. Keempat, rasa tertarik akan membuat seorang murid berminat terhadap sesuatu pelajaran maka murid tersebut akan tertarik dengan hal yang berkaitan dengan itu seperti guru, mata pelajaran, dan juga murid yang lainnya. $^{11}$

\footnotetext{
${ }^{9}$ Lusi Nurhayati, Psikologi Anak (Jakarta: PT Indeks, 2008), 59.

${ }^{10}$ Ahmad Susanto, Teori Belajar dan Pembelajaran (Jakarta: Kencana Prenada Media Grup, 2013), 60.

${ }^{11}$ Dwiati Yulianingsih, Stefanus Gaol, \& M.M. Lumban, (2019), Keterampilan Guru PAK untuk Meningkatkan Minat Belajar Murid dalam Proses 30 | Vol. 2 No. 2 (Juli-Desember 2018)
}

Slameto mengatakan belajar merupakan suatu proses usaha yang dilakukan seseorang untuk memperoleh suatu perubahan tingkah laku yang baru secara keseluruhan, sebagai hasil pengalamannya sendiri dalam interaksi dengan lingkungannya. ${ }^{12}$ Sedangkan Sardiman belajar merupakan perubahan tingkah laku atau penampilan, dengan serangkaian kegiatan misalnya dengan membaca, mengamati, mendengarkan, meniru dan lain sebagainya. ${ }^{13}$

\section{Keterampilan Guru Pendidikan Agama Kristen dalam Meningkatkan Minat Belajar}

Rusman mengatakan bahwa ada delapan ketrampilan dasar dari seorang guru profesional sebagai berikut: bertanya, memberi penguatan, mengadakan variasi, menjelaskan, membuka dan menutup pelajaran, membimbing diskusi kelompok kecil, mengelola kelas, dan mengajar kelompok kecil atau perorangan. ${ }^{14}$

Keterampilan Guru Pendidikan Agama Kristen dalam meningkatkan minat belajar dapat dibagi menjadi beberapa bagian yaitu:

(1) Membuka pelajaran di kelas yang menarik. Keterampilan membuka pelajaran adalah kegiatan yang dilakukan oleh guru guna menciptakan situasi agar murid siap mental untuk menaruh perhatian yang terpusat pada apa yang akan dipelajari.

(2) Prinsip dalam membuka pelajaran. Ada dua prinsip yaitu Prinsip kebermaknaan guru menarik perhatian murid dengan menggunaan cara-cara yang bermanfaat dan memiliki relevansi dengan materi pelajaran. Sedangkan prinsip berurutan dan berkesimabungan yaitu kegiatan yang sistematis dan berkaitan antara satu bagian dengan bagian lainnya atau berkaitan dengan pengetahuan awal para murid. Seperti yang

Pembelajaran di Kelas. FIDEI: Jurnal Teologi Sistematika dan Praktika. 2(1). DOI: 10.34081/fidei.v2i1.47.

${ }^{12}$ Slameto, Belajar dan Faktor-Faktor yang Mempengaruhinya (Jakarta: Remeka Cipta, 2010), 15.

${ }^{13}$ Sardiman, Interaksi dan Motivasi Belajar dan Mengajar (Jakarta: Rajawali Pers, 2011), 20.

${ }^{14}$ Rusman, Model-model Pembelajaran: Mengembangkan Profesionalisme Guru (Jakarta: Raja Grafindo Persada, 2014), 70. 
dikisahkan dalam Matius 16:5-10, setelah Tuhan Yesus mengadakan mujizat memberi makan lima ribu orang yang kemudian dilanjutkan dengan mujizat memberi makan empat ribu orang, Tuhan Yesus bersama murid-Nya menyeberangi danau. Langkah Tuhan Yesus untuk mengingatkan kepada para murid atas apa yang telah terjadi ini merupakan pelajaran penting bagi para murid untuk selalu mengingatnya. Materi pelajaran hari ini adalah kelanjutan dari materi dari pertemuan sebelumnya. Demkian juga materi hari ini akan dilanjutkan pada pertemuan yang akan datang.

(3) Memastikan proses belajar berlangsung dengan baik. Dalam memastikan proses belajar-mengajar di kelas berjalan baik, ada empat ketrampilan penting yang perlu diperhatikan oleh guru yaitu ketrampilan bertanya, penguatan, mengadakan variasi, dan ketrampilan dalam menjelaskan.

(4) Ketrampilan bertanya, adalah salah satu cara yang dapat dipakai oleh guru untuk membantu murid menerima informasi atau untuk mengembangkan ketrampilan kognitif yang lebih tinggi. Dalam kitab Injil mencatat bahwa Tuhan Yesus dalam mengajar sering mengajukan pertanyaan kepada murid-murid-Nya. Empat diantaranya adalah sebagai berikut: Pertama, dalam Injil Matius 26:8 Tuhan Yesus mengajukan pertanyaan "Mengapa kamu takut, kamu yang kurang percaya". Pertanyaan ini disampaikan untuk mengukur kadar iman para murid dan sekaligus bertujuan untuk membawa kembali tingkat kepercayaan yang lebih tinggi dari para murid kepada-Nya.

(5) Penguatan, adalah respon yang diberikan terhadap perilaku atau perbuatan yang dianggap baik, yang dapat membuat terulangnya atau meningkatnya perilaku atau perbuatan yang dianggap baik tersebut. ${ }^{15}$ Ketika Tuhan Yesus mengajar dengan perumpamaan tentang talenta (Mat. 35:1430), kepada hamba yang memiliki dua dan lima talenta yang telah mengembangkan talenta menjadi dua kali llipat itu dipuji

\footnotetext{
${ }^{15}$ Winataputra, Strategi Belajar Mengajar (Jakarta: Universitas Terbuka Departemen Pendidikan Nasional, 2007), 7-8.
}

dengan menyatakan bahwa perbuatannya itu baik sekali. Karena telah setia dalam perkara kecil maka tuannya akan menyiapkan tanggungjawab yang lebih besar.

(6) Mengadakan variasi. Tujuan penggunaan variasi adalah untuk mengatasi kejenuhan dan kebosanan sehingga suasana yang monoton dapat dihindari karena murid dengan antuisias dan penuh minat dalam mengikuti proses pembelajaran di kelas. Guru dapat bervariasi dalam penggunaan gaya mengajar, penggunaan media dan bahan ajar, serta dalam berinteraksi dengan murid apabila terlihat perhatian dan minat murid berkurang. Dalam Markus 4:2 mencatat bahwa Tuhan Yesus mengajar dengan menggunakan banyak perumpamaan. Archibald Hunter mengklaim bahwa 35 persen dari ajaran Tuhan dalam ke empat kitab Injil berbentuk perumpamaan. ${ }^{16}$

(7) Keterampilan menjelaskan adalah penyajian informasi secara lisan yang terorganisir secara sistematis untuk menunjukkan adanya hubugan antara satu dengan lainnya, contohnya hubungan sebab akibat. Tujuan dari menjelaskan adalah untuk membimbing murid memahami materi secara obyektif, melibatkan murid untuk berfikir memecahkan masalah atau menjawab suatu pertanyaan, memperoleh umpan balik dari murid untuk mengetahui tingkat pemahaman murid, dan membimbing murid memperoleh pengetahuan yang lebih bermakna dari proses penyelesaian masalah. Kotbah di bukit (Mat. 5-7) adalah contoh bentuk ceramah pengajaran Tuhan Yesus yang berisi nilai-nilai moral dan spiritual. Materi kotbah di bukit secara jelas dapat dilihat tingkat keteraturannya dan sistematika isinya, sehingga dengan mudah para murid dapat menyimaknya. Respon yang diharap dari para murid adalah pengertian yang lebih mendalam dan perubahan tingkah laku.

(8) Menutupan belajar di kelas yang mengesankan, adalah kegiatan yang dilakukan guru untuk memberikan gambaran menyeluruh tentang apa yang dipelajari murid yaitu mengetahui tingkat pencapaian murid. Pada tahap penutupan pelajaran ini guru memberikan dorongan secara psikologis dan

${ }^{16}$ A. Richad. Baley, New Testaments Issues (New York: Harper and Row, 2007), 70.

Excelsis Deo: Jurnal Teologi, Misiologi, dan Pendidikan | 31 
rohani. Dorongan secara psikologis mencakup tiga aspek yaitu aspek kognitif, afektif, dan psikomotorik. Dorongan secara rohani, guru Pendidikan Agama Kristen akan mengambil kesempatan pada bagian penutup ini untuk menegaskan dan menancapkan benih-benih Firman Tuhan sebagai materi ajar kepada para murid.

\section{KESIMPULAN}

Dari uraian tersebut dapat disimpulkan sebagai berikut:

Pertama, guru Pendidikan Agama Kristen bertanggung jawab bukan hanya menyampaikan materi ajar saja tetapi juga harus terampil untuk mengatasi segala hambatan belajar di kelas khususnya karena faktor murid yang tampak kurang antusias dan kurang berminat dalam mengikuti pelajaran di kelas.

Kedua, guru Pendidikan Agama Kristen wajib menguasai keterampilan dasar dalam menjalankan tugasnya. Penguasaaan keterampilan dasar mulai dari cara membuka kelas sampai penutupan mutlak dikuasai oleh guru supaya murid tetap berminat tinggi dan penuh antusias dalam belajar.

\section{Daftar Pustaka}

Baley, A. Richad. New Testaments Issues. New York: Harper and Row, 2007.

GP, Harianto. Komunikasi dalam Pemberitaan Injil. Yogjakarta: Andi,2012.

GP, Harianto. Pendidikan Agama Kristen dalam Alkitab \& Dunia Pendidikan Masa Kini. Yogjakarta: Andi, 2012.

Nainggolan, Johan M. Menjadi Guru Agama Kristen. Jakarta: Generasi Info Media, 2007

Nurhayati, Lusi. Psikologi Anak. Jakarta: PT Indeks, 2008.

Rusman. Model-Model Pembelajaran: Mengembangkan Profesionalisme Guru. Jakarta: Raja Grafindo Persada, 2014.

Sardiman. Interaksi dan Motivasi Belajar dan Mengajar. Jakarta: Rajawali Pers, 2011.
Sijabat, Samuel. Strategi Pendidikan Kristen. Yogjakarta: Andi, 1994.

Slameto. Belajar dan Faktor-Faktor Yang Mempengaruhinya. Jakarta: Remeka Cipta, 2010.

Suparlan. Menjadi Guru Efektif. Jakarta: Hikayat Publishing, 2008.

Susanto, Ahmad. Teori Belajar dan Pembelajaran. Jakarta: Kencana Prenada Media Grup, 2013.

Tim Penyusun. Kamus Besar Bahasa Indonesia. Jakarta: Balai Pustaka, 2001.

Undang Undang Republik Indonesia No 14 Tahun 20005 tentang Guru dan Dosen. Jakarta: Depdiknas, 2005.

Usman, Uzer. Menjadi Guru Profesional. Jakarta: Remaja Rosdakarya, 2006.

Winataputra. Strategi Belajar Mengajar. Jakarta: Universitas Terbuka Departemen Pendidikan Nasional, 2007.

Yulianingsih, Dwiati, Gaol, Stefanus, \& Lumban, M.M. (2019). Keterampilan Guru PAK untuk Meningkatkan Minat Belajar Murid dalam Proses Pembelajaran di Kelas. FIDEI: Jurnal Teologi Sistematika dan Praktika. 2(1). DOI: 10.34081/fidei.v2i1.47. 